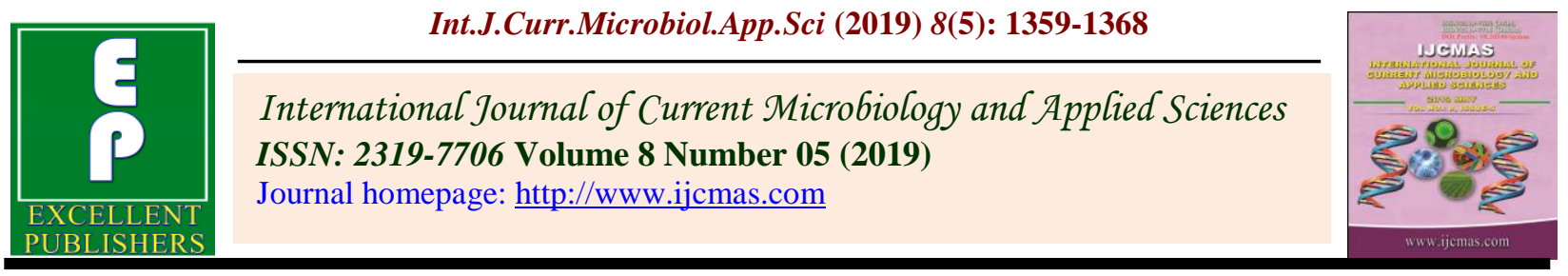

Original Research Article

https://doi.org/10.20546/ijcmas.2019.805.155

\title{
Marketing Pattern and Marketing Efficiency of Organic Large Cardamon and Ginger Spices Grown in East District of Sikkim, India
}

\author{
Archana Sharma and Amod Sharma*
}

Department of Agricultural Economics, Nagaland University SASRD, Medziphema Campus, District: Dimapur - 797 106, Nagaland, India

*Corresponding author

\begin{tabular}{|l|}
\hline Ke y w or d s \\
Large cardamom, \\
$\begin{array}{l}\text { Ginger, Marketing, } \\
\text { pattern, Efficiency, } \\
\text { Spices }\end{array}$ \\
\hline Article Info \\
\hline $\begin{array}{l}\text { Accepted: } \\
\text { 12 April } 2019 \\
\text { Available Online: } \\
\text { 10 May } 2019\end{array}$ \\
\hline \hline
\end{tabular}

A B S T R A C T

The present study on marketing pattern and marketing efficiency of organic large cardamom and ginger spices crops grown in East district of Sikkim state was initiated during the year 2017 to 2019 with the selection of 80 numbers of respondents and it was categorized into three groups viz., marginal, small and semi-medium size groups based on available cultivable land under the both selected spices crops. To achieve the specific objectives of the present study a multi stage purposive stratified random sampling method was adopted. Further data reveals that on the selected farm size group the majority of the respondents (50.00 per cent) belonged to small land holding with an area of 1.01 ha to 2.00 ha. While in the marketing of ginger, the highest cost was incurred by processor (Rs.6.08) in Channel II followed by Producer (Rs1.5) in Channel I. The total marketing cost was higher in Channel II (Rs. 7.42/Kg) than Channel I (Rs.3.21/Kg). Total marketing margin was found to be the highest in Channel II (Rs.247.64) than Channel I (Rs.41.89). The largest chunk of margin was enjoyed by the producers in Channel II (Rs.219.5 per Kg) followed by processor in channel II (Rs.13.93 per Kg). On assessing efficiency, through Conventional method it was found that Channel II was more efficient (4.72 per cent) as compared to Channel I (2.21 per cent). Through Shepherd method also Channel II was found to be more efficient (34.37 per cent) than Channel I (14.05 per cent). Through Acharya's method Channel II was found to be more efficient ( 0.86 per cent) than Channel I $(0.84$ per cent $)$, respectively. The producer's share in consumer's price was found to be high in channel II (97.09 per cent) than Channel I (92.88 per cent), respectively.

\section{Introduction}

IFOAM defines organic agriculture as "a production system that sustains the health of soils, ecosystems and people. It relies on ecological processes, biodiversity and cycles adapted to local conditions instead of using inputs with adverse effects. Organic agriculture combines tradition, innovation and science to promote fair relationships and a good standard of life for all involved (IFOAM, 2019).

Large cardamom (Amomum subulatum, Roxb) is a member of the family Zingiberacea under the order Scitaminae (Bisht et al., 2011). It is 
believed that Sikkim is the place of origin for cardamom (Adhikari, 2016). Nepal is the largest producer of large cardamom in the world; more than 95.00 per cent of the produce is marketed to India, the largest exporter of large cardamom (Sharma et al., 2018).

Ginger (Zingiber officinale Rosc.) is cultivated in India, China, Japan, Indonesia, Australia, Nigeria and West Indies. India is the largest producer and consumer of ginger in the world (Anonymous, 2018). It is one among the regionally advantageous crops in the Northeast India. Among North Eastern States, Sikkim ranks third in area and fifth in production as well as productivity (Rahman et al., 2007).

Bhutia et al., (2017) in their paper entitled "Post-harvest and value chain management of large cardamom in hills and uplands" have mentioned that the post-harvest value chain consisted of growers, collectors, traders, and exporters. The losses in the field vary from 5.00 to 10.00 per cent which may go up to 80.00 per cent in case of disease affected materials. India exports large cardamom to Australia, Canada, Pakistan, UK, etc. They also mentioned that Singtam, Gangtok, Jorethang, Rongli, and Mangan etc.are the major local markets in Sikkim. Siliguri is the main trade link from where it is distributed to Guwahati, Kolkata and Delhi (Willan and Larnold, 2008).

Agriculture marketing is not regulated in the state so the marketing of horticultural produce is unorganized. Largest fruits and vegetables market is Kanchenjunga Complex in Gangtok which is occupied by wholesalers and retailers. NERAMAC, SIMFED and few farmers' groups and individuals have outlets in the complex. There is no other facility available as per the APMC guideline. Government made effort to organize horticulture trade by locating it under one regulated market in East Sikkim but due to non-interest of traders it could not be implemented (Anon, 2017; APEDA, 2019).

\section{Materials and Methods}

Sikkim is a small state with only four districts and sixteen sub-divisions. This state was chosen primarily due to the lack of academic research in the field of post-harvest as well as marketing of organic spices. Spices are grown in almost all the districts; however large cardamom and ginger are the two major cash crops and important source of income for the farmers in the East district of Sikkim, which is also a hub of all administrative activities. For the present study out of total eight developmental blocks two blocks were selected randomly viz., Khamdong and Regu. For the marketing cost and post-harvest activities / information altogether 10 numbers of marketing agencies were selected with the help of FPO's and Progressive organic farmers viz., 5 wholesalers and 3 retailers along with two marketing institutes viz. SIMFED and NERAMAC all are actively functional in the state with the help of the Assistant Managers of both the institutes.

\section{Price variation in different marketing channels}

The marketing cost was calculated by estimating the cost incurred in the process of marketing of the two crops depending on their channels.

\section{Marketing margin}

Marketing margin was calculated as follows. $\mathrm{MM}_{\mathrm{i}}=\mathrm{SP}_{\mathrm{i}}-\left(\mathrm{PP}_{\mathrm{i}}+\mathrm{MC}_{\mathrm{i}}\right)$

Whereas: $\mathrm{MM}_{\mathrm{i}}=$ Marketing margin of the $\mathrm{i}-\mathrm{th}$ middleman, 
$\mathrm{SP}_{\mathrm{i}}=$ Selling price of the $\mathrm{i}$-th middleman,

$\mathrm{PP}_{\mathrm{i}}=$ Purchasing price of the $\mathrm{i}$-th middleman,

$\mathrm{MC}_{\mathrm{i}}=$ Marketing cost incurred by the i-th middleman

\section{Marketing efficiency}

There are three methods of calculating marketing efficiency. The degree of market performance was calculated using all the three methods as discussed below.

Ratio of output to input (Conventional method)

$M E=O / I \times 100$

Whereas: $\mathrm{ME}=$ Index of marketing efficiency,

$\mathrm{O}=$ Value added,

$\mathrm{I}=$ Marketing cost

Value added $=$ Difference between the price paid by the consumer to price received by the producers.

\section{Shepherd's method}

$M E=C P / M C$

Whereas: $\mathrm{ME}=$ Index of marketing efficiency, $\mathrm{CP}=$ consumer's purchase price and $\mathrm{MC}=$ Total marketing cost.

\section{Acharya's method}

$M M E=F P /(M C+M M)$

Whereas: $\mathrm{MME}=$ Modified measure of index of marketing efficiency, $\mathrm{FP}=$ Price received by farmer, $\mathrm{MM}=$ Marketing margin, $\mathrm{MC}=$ Total marketing cost .

\section{Price spread}

Price spread is the difference between the price paid by the consumer and the price received by the producer. It mainly consists of marketing costs and margins. The price spread analysis was carried out as follows:

Producer' s share in consumer' s rupee $=\frac{\text { Producer' } \quad \text { s price }}{\text { Consumer' } \quad \text { s price }} \times 100$

\section{Results and Discussion}

Marketing pattern and marketing efficiency of organic large cardamom

Large cardamom and ginger being spice crops, farmers usually do not retain the produce for family consumption. Thus, the entire quantity of the produce is available as marketable surplus. In the present study two channels were identified in the marketing of large cardamom.

Channel I: Producer - Wholesaler- Dealer from terminal markets

Channel II: Producer - Auction centre Dealer from terminal markets

Terminal market is one where the produce is either finally disposed of to the consumers or processors or assembled for export.

Table 1 reveals that the marketing cost incurred by the intermediaries of two channels in the marketing of large cardamom. The Total marketing cost was found to be higher in channel I (Rs.15.65/-per kg), as the marketing cost was comparatively lower in channel II (Rs. 6.80/- per $\mathrm{kg}$ ) due to the prevalence of auction system. It also shows that the wholesalers incurred highest marketing cost (Rs. 8.90/- per kg), followed by producers (Rs. 3.50/- per kg) in Channel I, respectively. Similar study was also carried out by Sharma (2011) (Fig. 1-4). 
Table 2 reveals that the marketing margin of the intermediaries at various stages of marketing. Total marketing margin was found to be the highest in Channel II (Rs. 1,151.50). The largest chunk of margin was enjoyed by the dealers from terminal markets in channel II (Rs. 575.75/- per kg), followed by producer in channel II (Rs. 573.20/- per $\mathrm{kg}$ ), respectively.

Table 3 reveals that the empirical assessment of marketing efficiency of large cardamom. Through Conventional method it was found that Channel II was more efficient (30.26 per cent) as compared to Channel I (17.89 per cent), while through Shepherd method the Channel II was found to be more efficient (114.71 per cent) than Channel I (49.84 per cent), respectively. Through Acharya's method Channel II was found to be more efficient (0.99 per cent) than Channel I (0.95 per cent), respectively (Sharma and Sharma, 2014).

Table 4 reveals that the price spread in marketing of large cardamom. The producer's share in consumer's price was found to be high in channel II (99.13 per cent) than Channel I (97.99 per cent), respectively. Similar study was also carried out by Sharma (2011).

\section{Marketing pattern and Marketing efficiency of organic ginger}

While in the marketing of ginger two channels were identified.

Channel I: Producer - Wholesaler - Retailer Consumer

Channel II: Producers - Processors Wholesaler - Retailer - Consumer

Table 5 reveals that the cost incurred by the intermediaries in marketing of ginger. The highest cost was incurred by processor (Rs 6.08/-) in Channel II, followed by Producer (Rs 1.50/-) in Channel I, while the total marketing cost was higher in Channel II (Rs 7.42 per kg) than Channel I (Rs 3.21 per kg), respectively. Similar study was also carried out by Sharma et al., (2016) (Fig. 5-8).

Table.1 Marketing cost of large cardamom (in Rs per kg)

\begin{tabular}{|c|l|c|c|}
\hline Sl. No. & \multicolumn{1}{|c|}{ Category } & Channel I & Channel II \\
\hline 1. & Producer & 3.50 & 1.00 \\
\hline 2. & Auction centre & 0.00 & 2.55 \\
\hline 3. & Wholesalers & 8.90 & 0.00 \\
\hline 4. & Dealers from terminal markets & 3.25 & 3.25 \\
\hline & Total marketing cost & 15.65 & 6.80 \\
\hline
\end{tabular}

Table2 Marketing margin of large cardamom

\begin{tabular}{|c|l|c|c|}
\hline Sl. No. & \multicolumn{1}{|c|}{ Category } & Channel I & Channel II \\
\hline 1. & Producer & 496.50 & 573.20 \\
\hline 2. & Auction centre & 0.00 & 2.55 \\
\hline 3. & Wholesalers & 15.10 & 0.00 \\
\hline 4. & Dealers from terminal markets & 511.60 & 575.75 \\
\hline \multicolumn{2}{|c|}{ Total marketing margin } & 1023.20 & 1151.5 \\
\hline
\end{tabular}


Table.3 Marketing efficiency of large cardamom

\begin{tabular}{|c|l|c|c|}
\hline Sl. No. & \multicolumn{1}{|c|}{ Particulars } & Channel I & Channel II \\
\hline 1. & Consumer's price (CP) $(\mathrm{Rs} / \mathrm{Kg})$ & 780.00 & 780.00 \\
\hline 2. & Total marketing cost (MC) (Rs / Kg) & 15.65 & 6.80 \\
\hline 3. & Total margins of intermediaries $(\mathrm{MM})(\mathrm{Rs} / \mathrm{Kg})$ & 511.60 & 575.75 \\
\hline $\mathbf{4 .}$ & Price received by farmers $(\mathrm{FP})(\mathrm{Rs} / \mathrm{Kg})$ & 500.00 & 574.20 \\
\hline $\mathbf{5 .}$ & Value added by the marketing system & 280.00 & 205.80 \\
\hline \multicolumn{3}{|c|}{ Index of Marketing Efficiency (Percentage) } \\
\hline 6. & Conventional method & 17.89 & 30.26 \\
\hline $\mathbf{7 .}$ & Shepherd's method & 49.84 & 114.71 \\
\hline $\mathbf{8 .}$ & Acharya's method & 0.95 & 0.99 \\
\hline
\end{tabular}

Table.4 Price spread of large cardamom in different channels

\begin{tabular}{|c|l|c|c|}
\hline SI. No. & \multicolumn{1}{|c|}{ Particulars } & Channel I & Channel II \\
\hline 1. & Terminal market price (Consumer's price) & 780.00 & 780.00 \\
\hline 2. & Total marketing cost (Rs / kg) & 15.65 & 6.80 \\
\hline 3. & Total marketing margin (Rs / kg) & 511.60 & 575.75 \\
\hline 4. & Producer's share in consumer price (\%) & 97.99 & 99.13 \\
\hline
\end{tabular}

Table.5 Marketing cost of ginger in different channels

\begin{tabular}{|c|c|c|c|}
\hline Sl. No. & Category & Channel I & Channel II \\
\hline $\mathbf{1 .}$ & Producer & 1.50 & 0.55 \\
\hline $\mathbf{2 .}$ & Processor & 0.00 & 6.08 \\
\hline 3. & Wholesaler & 0.96 & 0.28 \\
\hline 4. & Retailer & 0.75 & 0.52 \\
\hline \multicolumn{2}{|c|}{ Total marketing cost } & 3.21 & 7.42 \\
\hline
\end{tabular}

Table.6 Marketing margin in different channels of ginger

\begin{tabular}{|c|c|c|c|}
\hline Sl. No. & Category & Channel 1 & Channel II \\
\hline 1. & Producer & 36.50 & 219.50 \\
\hline 2. & Processor & 0.00 & 13.93 \\
\hline 3. & Wholesaler & 4.04 & 7.23 \\
\hline 4. & Retailer & 1.35 & 6.99 \\
\hline \multicolumn{2}{|c|}{ Total marketing margin } & 41.89 & 247.64 \\
\hline
\end{tabular}


Table.7 Marketing efficiency in different marketing channels of ginger

\begin{tabular}{|c|l|c|c|}
\hline SI. No. & \multicolumn{1}{|c|}{ Particulars } & Channel I & Channel II \\
\hline $\mathbf{1 .}$ & Consumer's price $(\mathrm{Rs} / \mathrm{Kg})$ & 45.10 & 255.00 \\
\hline $\mathbf{2 .}$ & Total marketing cost $(\mathrm{MC})(\mathrm{Rs} / \mathrm{Kg})$ & 3.21 & 7.42 \\
\hline $\mathbf{3 .}$ & $\begin{array}{l}\text { Total margins of intermediaries }(\mathrm{MM}) \\
(\mathrm{Rs} / \mathrm{Kg})\end{array}$ & 41.89 & 247.63 \\
\hline $\mathbf{4 .}$ & Price received by farmers(FP) $(\mathrm{Rs} / \mathrm{Kg})$ & 38.00 & 220.00 \\
\hline $\mathbf{5 .}$ & Value added by the marketing system & 7.10 & 35.00 \\
\hline & \multicolumn{1}{|c|}{ Index of Marketing Efficiency (Percentage) } \\
\hline $\mathbf{6 .}$ & Conventional method & 2.21 & 4.72 \\
\hline $\mathbf{7 .}$ & Shepherd's method & 14.05 & 34.37 \\
\hline $\mathbf{8 .}$ & Acharya's method & 0.84 & 0.86 \\
\hline
\end{tabular}

Table.8 Price spread in different marketing channels of ginger

\begin{tabular}{|c|l|c|c|}
\hline Sl. No. & \multicolumn{1}{|c|}{ Particulars } & Channel I & Channel II \\
\hline 1. & Consumer's price (Rs./Kg) & 45.10 & 255.00 \\
\hline 2. & Total marketing cost (Rs./kg) & 3.21 & 7.42 \\
\hline 3. & Total marketing margin (Rs./kg) & 41.89 & 247.63 \\
\hline 4. & $\begin{array}{l}\text { Producer's share in consumer price } \\
(\%)\end{array}$ & 92.88 & 97.09 \\
\hline
\end{tabular}

Fig.1 Marketing cost of large cardamom $(\mathrm{Rs} / \mathrm{Kg})$ in different marketing channels

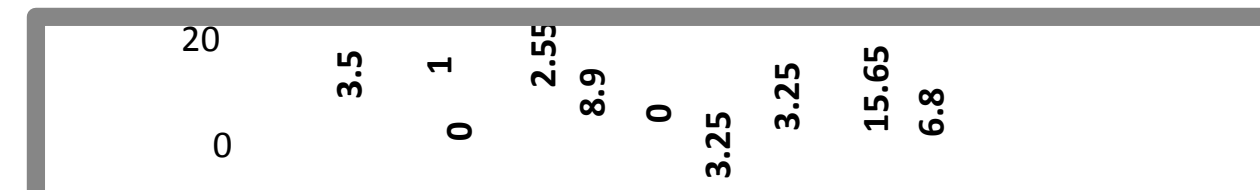

Channel

1 
Fig.2 Marketing margin in different marketing channels of large cardamom

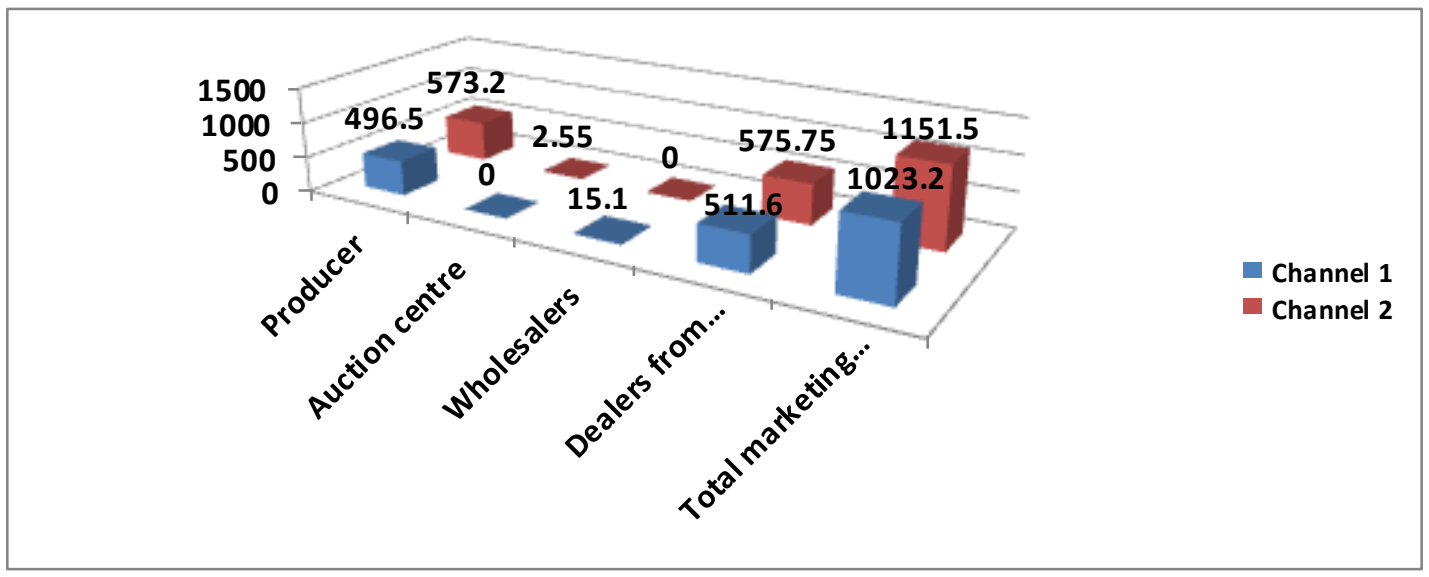

Fig.3 Index of marketing efficiency in different channels of large cardamom marketing

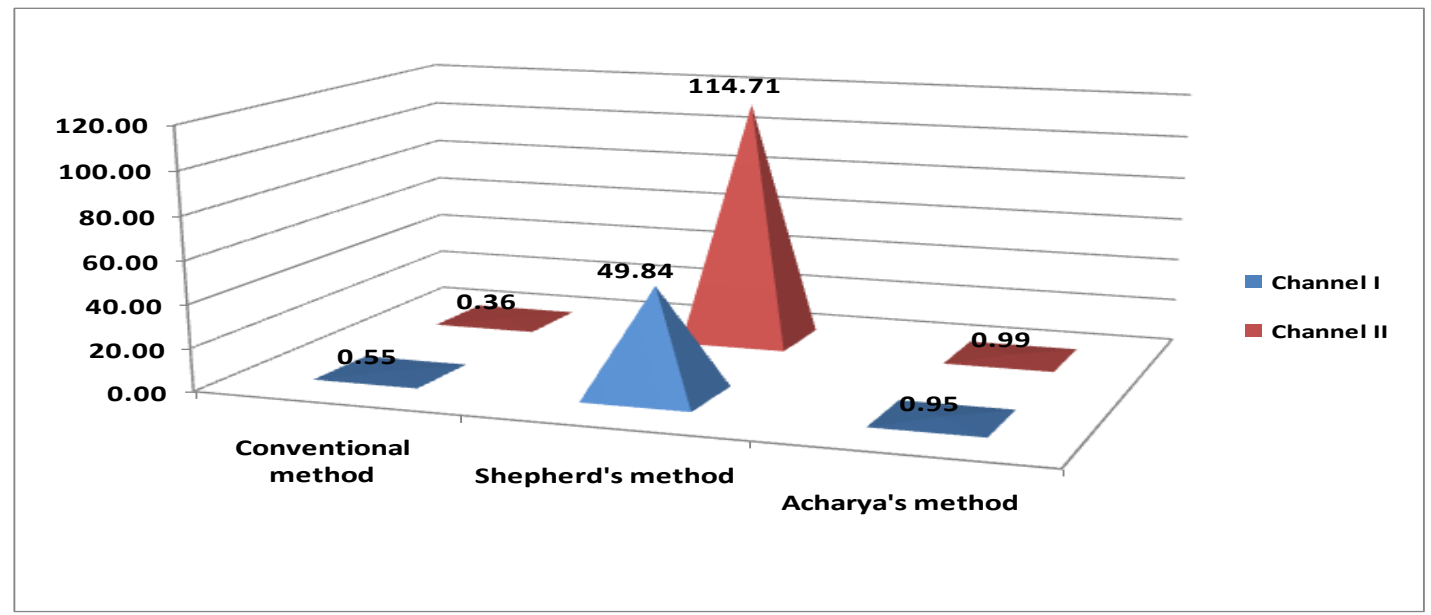

Fig.4 Price spread in different marketing channels of large cardamom

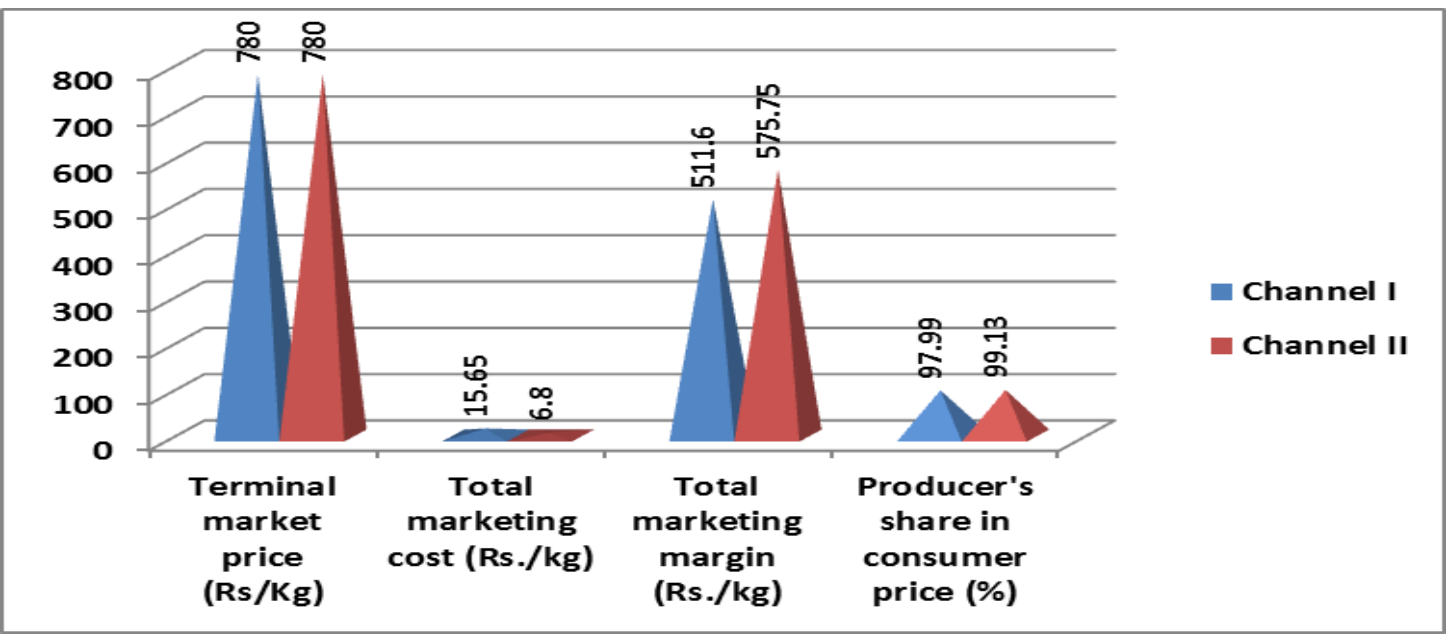


Fig.5 Marketing cost in different marketing channels of ginger

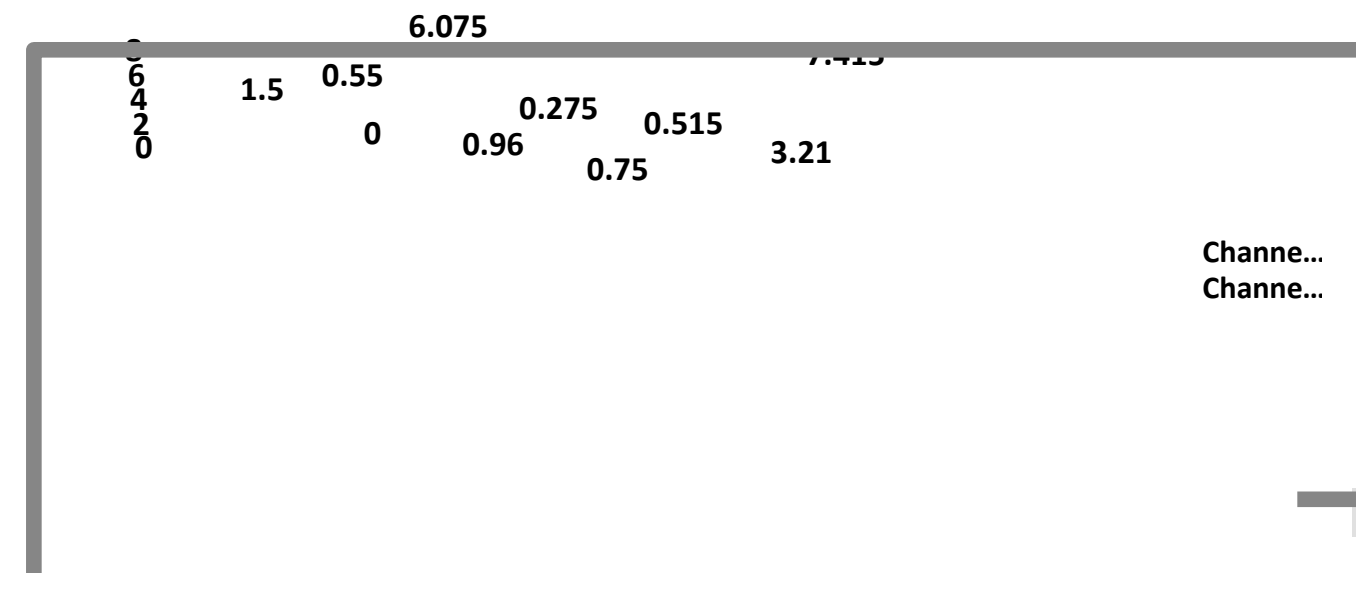

Fig.6 Marketing margin in different marketing channels of ginger

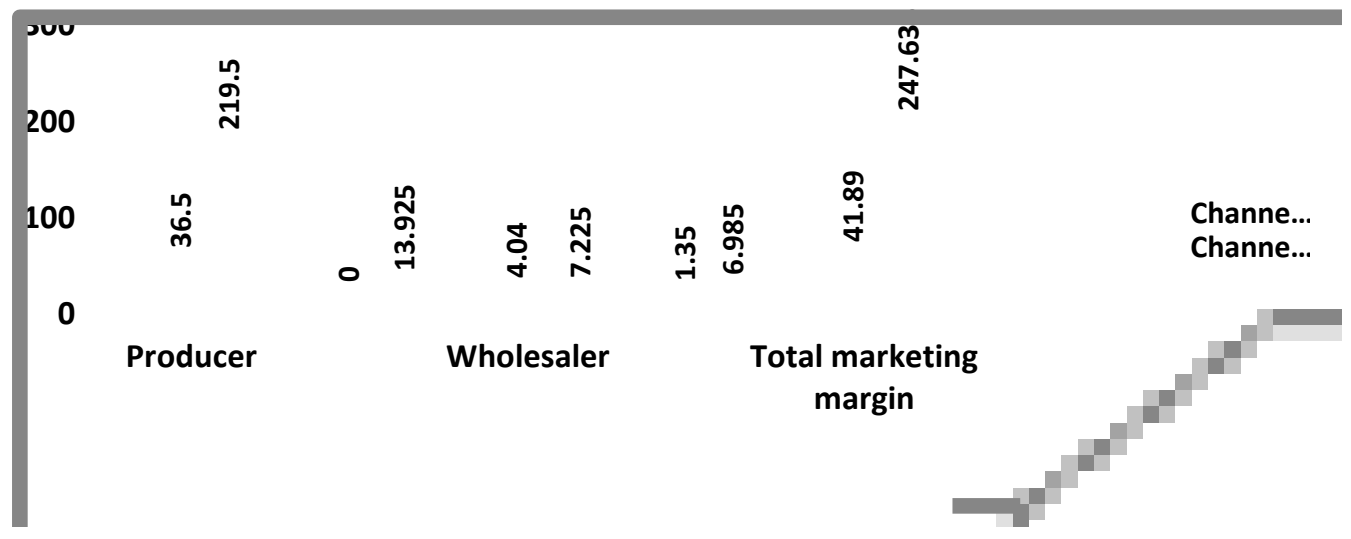

Fig.7 Index of marketing efficiency in different marketing channels of ginger

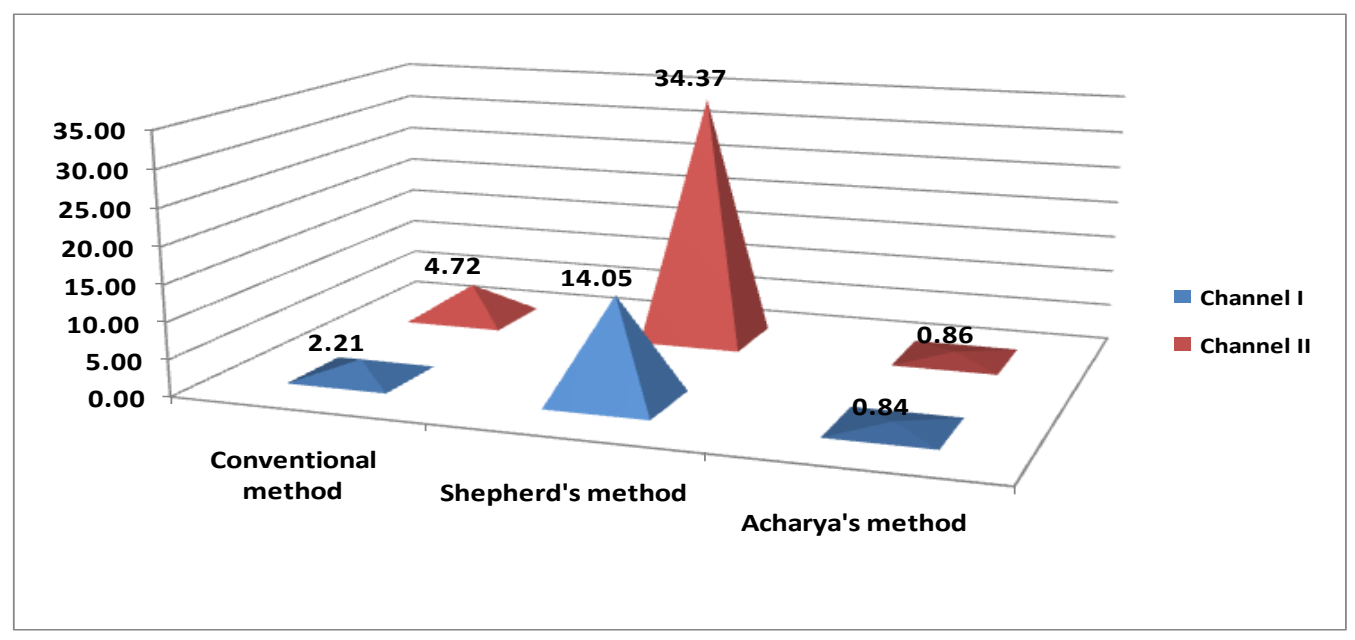


Fig.8 Price spread in different marketing channels of ginger

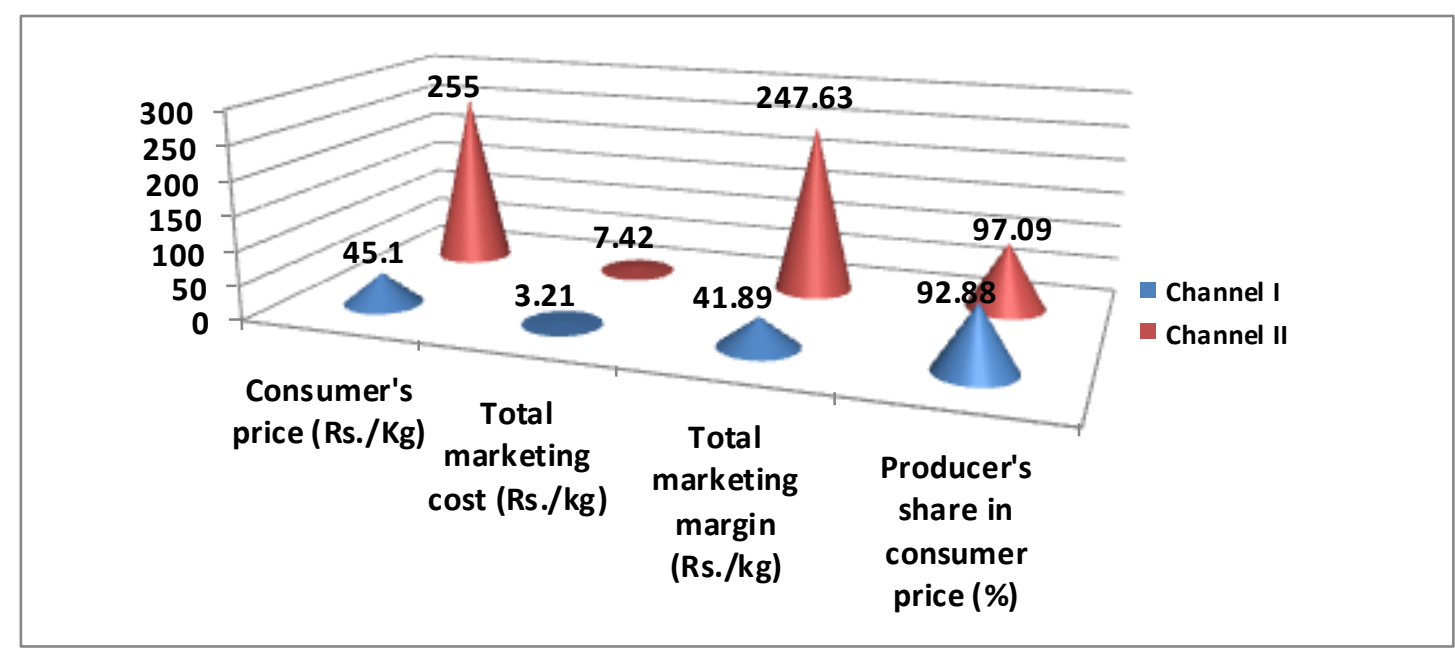

Table 6 reveals that the marketing margin of the intermediaries at various stages of marketing. Total marketing margin was found to be the highest in Channel II (Rs 247.64/-) than Channel I (Rs 41.89/-), respectively. The largest chunk of margin was enjoyed by the producers in Channel II (Rs 219.50/- per kg), followed by processor in channel II (Rs 13.93/- per kg), respectively. Similar study was also carried out by Sharma (2012).

Table 7 reveals that the empirical assessment of marketing efficiency of ginger. Through Conventional method it was found that Channel II was more efficient (4.72 per cent) as compared to Channel I (2.21 per cent), respectively. While, through Shepherd method the Channel II was found to be more efficient (34.37 per cent) than Channel I (14.05 per cent), respectively. Through Acharya's method Channel II was found to be more efficient ( 0.86 per cent) than Channel I (0.84 per cent), respectively. Similar study was also carried out by Shuya and Sharma (2014).

Table 8 reveals that the price spread in marketing of large cardamom. The producer's share in consumer's price was found to be high in channel II (97.09 per cent) than
Channel I (92.88 per cent), respectively. Similar study was also carried out by Sharma and Sharma (2008).

It is concluded that, in the marketing of ginger, the highest cost was incurred by processor (Rs 6.08/p-) in Channel II, followed by Producer (Rs 1.50/-) in Channel I, the total marketing cost was higher in Channel II (Rs 7.42/- per kg) than Channel I (Rs 3.21/- per $\mathrm{kg}$ ). While the total marketing margin was found to be the highest in Channel II (Rs 247.64/-) than Channel I (Rs 41.89/-). The largest chunk of margin was enjoyed by the producers in Channel II (Rs 219.50/- per kg), followed by processor in channel II (Rs 13.93/- per $\mathrm{kg}$ ) on assessing efficiency, through Conventional method it was found that Channel II was more efficient (4.72 per cent) as compared to Channel I (2.21 per cent), respectively. While through Shepherd method the Channel II was found to be more efficient (34.37 per cent) than Channel I (14.05 per cent), respectively. Through Acharya's method Channel II was found to be more efficient ( 0.86 per cent) than Channel I (0.84 per cent), respectively. The producer's share in consumer's price was found to be high in channel II (97.09 per cent) than Channel I (92.88 per cent), respectively. 


\section{References}

Adhikari, P.P. 2016. Cardamom cultivation technology, Agriculture Information and Communication Center, Hariharbhawan Lalitpur, Nepal.

Analogous. 2018. Statistical Hand of Sikkim Published by Directorate of Economics and Statistics (various issues), Gangtok, Sikkim.

Anonymous. 2017. Marketing strategies for organic produce of Sikkim, A report submitted to Sikkim Organic Mission, Government of Sikkim, Gangtok, CGS National Institute of Agricultural Marketing. Ministry of Agriculture and Farmers Welfare, Kota road, Bambala, Pratap Nagar, Jaipur, India.

Bhutia, P.H., Sharangi, A.B., Lepcha, R. and Yonzone, R. 2017. Post-harvest and value chain management of large cardamom in hills and uplands. International Journal of Chemical Studies. 6(1): 505-511.

Bisht, V.K., Negi, A.K. and Bhandari, A.K. 2011. Ammomum subulatum cardamom: Traditional Phytochemical and Biological Activities - An overview. African Journal of Agriculture Research, 8(24): 5388-5390.

http://apeda.gov.in/apedawebsite/organic/Organ ic_Products. Assessed on 13 March 2019.

https://www.ifoam.bio/sites/default/files/page/fi les/ifoamstandarddraftv1.1_forconsultat ion_clean_new.doc. Assessed on 23 April 2019.

Rahman, H., Bujarbaruah, K.M., Srivastava, L.S., Karuppaiyan, R., Avasthe R.K. and Singh, M. 2007. Status of ginger cultivation in Sikkim with special reference to disease management. ICAR Research Complex for NEH Region Sikkim Centre, Tadong, Gangtok.

Sharma, A. and Sharma, Anamika. 2008. Problems faced by the farmers in adoption of improved maize cultivation practices in hills. TJRAR. 8(2): 22-23.

Sharma, Amod. 2011. Economic and Constraints of King Chilli Growers in Dimapur District of Nagaland. Journal of Interacademicia. 15(4): 710-719.

Sharma, Amod. 2012. Inter-state Disparities in Socio-economic Development in North East Region of India. Journal of Agricultural Science. 4(9). September: 236-243.

Sharma, Amod., Kichu, Yimkumba. and Chaturvedi, B. K. 2016. Economics and Constraints of Pineapple Cultivation in Dimapur District of Nagaland. TJRAR. 16(1). January: 72-75.

Sharma, Amod., Kichu, Yimkumba. and Sharma, Pradeep. Kumar. 2018. Sustainable economic analysis and constraints faced by the pineapple growers in Nagaland. Progressive Agriculture. 18(1). February: 27-33.

Shuya, Keviu. and Sharma, Amod. 2014. Impact and constraints faced by the borrowers of cooperative bank finance in Nagaland. Economic Affairs. 59(4). October: 561-567.

Willer, H. and Lernoud, J. 2018. The world of organic agriculture. Statistics and emerging trends 2018. Research Institute of Organic Agriculture (FiBL), Frick, and IFOAM - Organics International, Bonn.

\section{How to cite this article:}

Archana Sharma and Amod Sharma. 2019. Socio Marketing Pattern and Marketing Efficiency of Organic Large Cardamon and Ginger Spices Grown in East District of Sikkim, India. Int.J.Curr.Microbiol.App.Sci. 8(05): 1359-1368. doi: https://doi.org/10.20546/ijcmas.2019.805.155 